\title{
BMP7 as a multifactorial growth factor for cartilage homeostasis
}

Citation for published version (APA):

Ripmeester, E. G. J. (2021). BMP7 as a multifactorial growth factor for cartilage homeostasis. [Doctoral Thesis, Maastricht University]. Maastricht University. https://doi.org/10.26481/dis.20210930er

Document status and date:

Published: 01/01/2021

DOI:

10.26481/dis.20210930er

Document Version:

Publisher's PDF, also known as Version of record

\section{Please check the document version of this publication:}

- A submitted manuscript is the version of the article upon submission and before peer-review. There can be important differences between the submitted version and the official published version of record.

People interested in the research are advised to contact the author for the final version of the publication, or visit the DOI to the publisher's website.

- The final author version and the galley proof are versions of the publication after peer review.

- The final published version features the final layout of the paper including the volume, issue and page numbers.

Link to publication

\footnotetext{
General rights rights.

- You may freely distribute the URL identifying the publication in the public portal. please follow below link for the End User Agreement:

www.umlib.nl/taverne-license

Take down policy

If you believe that this document breaches copyright please contact us at:

repository@maastrichtuniversity.nl

providing details and we will investigate your claim.
}

Copyright and moral rights for the publications made accessible in the public portal are retained by the authors and/or other copyright owners and it is a condition of accessing publications that users recognise and abide by the legal requirements associated with these

- Users may download and print one copy of any publication from the public portal for the purpose of private study or research.

- You may not further distribute the material or use it for any profit-making activity or commercial gain

If the publication is distributed under the terms of Article $25 \mathrm{fa}$ of the Dutch Copyright Act, indicated by the "Taverne" license above, 
Osteoarthritis $(\mathrm{OA})$ is the most common chronic joint condition. However, treatment of osteoarthritis is mainly symptomatic by alleviating pain to postpone total joint replacement, while disease-modifying drugs have not reached the clinic yet. Understanding the molecular pathways involved in OAdisease initiation and progression is of great importance to allow for the identification of new molecular treatment targets.

The studies described in this thesis demonstrate how BMP7 bioactivity can influence different $\mathrm{OA}$ chondrocyte phenotypes and may potentially be used in treatment of $\mathrm{OA}$. We identified peptides mimicking BMP7 bioactivity, which can positively influence the OA chondrocyte phenotype. Additionally, we demonstrated an interaction between BMP7 and chondrocyte protein translational capacity. This novel biomolecularknowledge may provide novel avenues for the development of future OA disease-modifying treatments.
BMP7 as a Multifactorial Growth Factor for Cartilage

3 .

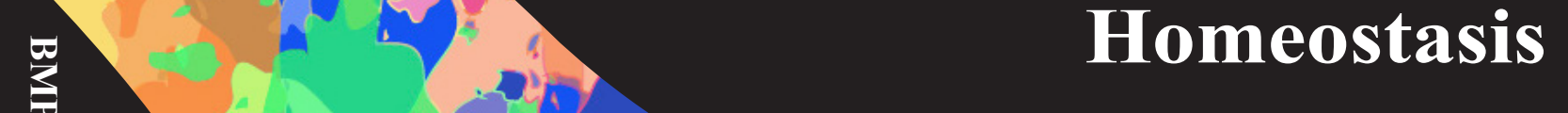

\section{$\rightarrow$}

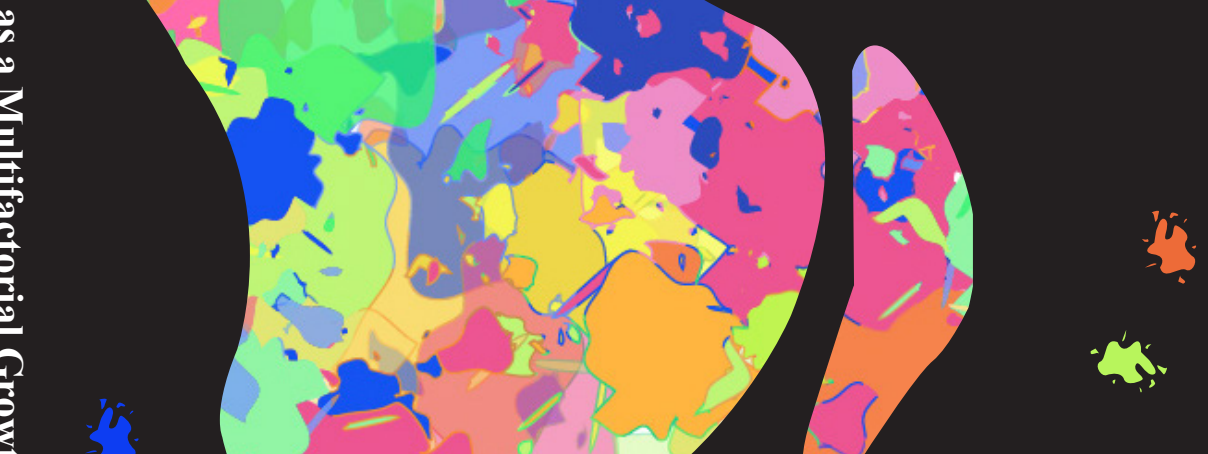

